\title{
Lesbian, Gay, Bisexual, and Transgender and Alternative Policies for Its Alleviation in Minangkabau Community
}

\author{
Yulfira Media ${ }^{1, *}$ Alfitri $^{2}$ \\ ${ }^{1}$ Research and Development Research and Development Padang, Indonesia \\ ${ }^{2}$ Indonesia Doctoral Study Program Department of guidance and Counseling, Faculty and Education, Universitas \\ Negeri Padang, Padang, Indonesia \\ *Corresponding author. Email: Fira.media@yahoo.com
}

\begin{abstract}
Nowadays, phenomenon of LGBT has been increasing and needs to get a serious attention in West Sumatra because it is the biggest risk of HIV / AIDS transmission. This research is to describe the phenomenon of LGBT and alternative policies for its alleviation in Minangkabau community (West Sumatra Province). It is a mixed methods research. Data were collected through interview technique using 147 respondents, Focus Group Discussion (FGD) and in-depth interview with LGBT. It was analyzed quantitatively and qualitatively. The results of the research show that most of respondents (51.03\%) were in the age group of 15-25 years old. The age of firstly starting the same sex under the age of 12 years old is $32.7 \%$. There are less harmonious environmental and family factors causing LGBT problem. Then, some of them have never received the religious assistance from experts $(75.51 \%)$ and psychologists $(68.7 \%)$. Alternative policy directions in the prevention of LGBT are increasing knowledge about LGBT prevention, optimizing the strengthening of family resilience, improving the application of sociocultural and religious values, and optimizing the monitoring of the social environment. LGBT behavior has been carried out since a young age and it needs alternative policies in order to achieve an integrated alleviation.
\end{abstract}

Keywords: LGBT, policy, alleviation, sociocultural

\section{INTRODUCTION}

Phenomenon of homosexuality or "Lesbian, Gay, Bisexual, and Transgender" (LGBT) has been growing rapidly in Indonesia because the border of freedom is really open. That is why open campaigns can be carried out by playing on the issue of Human Rights. This condition has already made the LGBT communities more solid to influence common young people by various modes and the existence of activists who are considered as heroes to fight for the existence of LGBT [1].

The development of LGBT community numbers has increasingly been worrying because it tends to raise, and it is even the greatest risk in HIV / AIDS transmission. Globally, man, who have sex with man (MSM), is 24 times more at risk of HIV infection than the general population. In 2015, the result of the Integrated Biological Behavior Survey reveals that $25.80 \%$ of HIV prevalence originated from man has sex with men and $24.82 \%$ from transvestites [2].

The current LGBT phenomenon in West Sumatra Province also needs serious attention. Estimation from the National Aids Prevention Commission in 2016 informs that the number of MSM and transvestites in West Sumatra is 15,371 people. Further data on the cumulative number of HIV /AIDS cases in West Sumatra reported that from 1987 to 2017: HIV cases were 2,446, and AIDS cases were 1611 [3]. Actually, majority of the Minangkabau tribes is well-known as strong and steadfast followers of Islam in their custom, but this phenomenon has caused all elements of society in West Sumatra feel worried about LGBT behavior.

LGBT phenomenon has a negative impact not only in terms of one's health or personality, but it can also erode and challenge the harmony of community life. From the sociological point of view, it will cause an increase in social and immoral symptoms where it makes it difficult to control. These bad habits, from the psychological point of view, will affect the soul and have a very strong effect on the nerves. As a result, the perpetrators feel that they are not real men or women, and worried about their own identity and sexuality [4].

Related to the same-sex sexual behavior, the results of a study of Man Sex Man (MSM), HIV/ AIDS and sexual behavior in Semarang in 2017 reveal that the cause of men with heterosexual sexual orientation decides to have sex with other with homosexual orientation men because of getting the temptation when their psychical condition is not good for example: having a problem with family or wife; and feeling in need of love from an adult male due to not having complete parents from birth [5].

The problem of LGBT is increasingly worrying for the younger generation today. Moreover, it is supported by the 
condition of families who are vulnerable to conflict. The formed values in the family and the family's parenting will influence the building of a child's sexual orientation. This causes emotional disturbances affecting children's psychosocial development. Due to the increasing number of LGBT cases in West Sumatra and the absence of research related to policies on LGBT prevention, it is necessary to conduct a research related to LGBT behavior in Minangkabau community (West Sumatra Province) and alternative policies in their alleviation. The purpose of this research was to describe the LGBT phenomenon and alternative policies for its alleviation in Minangkabau community.

\section{METHOD}

The study was conducted in Padang City, Bukittinggi, Solok City and Solok Regency in 2018. Fields of the research were based on the estimation result of risk groups where Padang was the highest LGBT group in West Sumatra. Bukittinggi is the highest transvestite group in West Sumatra. Meanwhile, Solok City and Solok Regency are the top five LGBT risk places in West Sumatra and there is one HIV referral Hospital AIDS in West Sumatra. This research was a mix method research. This method is a method focusing on how to collect, analyze, and combine data of quantitative and qualitative research methods in one study or series research. ${ }^{[6]}$ Data collection techniques were carried out through interviews with 147 respondents (LGBT) using a questionnaire. Subsequently, it was continued by Focus Group Discussion and in-depth interviews with LGBT. Data were analyzed quantitatively and qualitatively.

\section{RESULTS AND DISCUSSION}

\section{Phenomenon of LGBT}

Based on the results of the study, it reveals that the highest frequency of age is in the group of 15-25 years old $(51.03 \%)$, and the largest respondent age of starting to like the same sex or both is in the age of 12-18 years old $(44.2 \%)$, and it is followed by the age of group $<12$ years old for $32.7 \%$. In terms of sex, the majority of respondents were male for $83.7 \%$. Furthermore, most respondents' education is $71.4 \%$ of Senior High School graduates (table $1)$.

Table 1. Respondent criteria $(N=147)$

\begin{tabular}{|c|c|}
\hline Criteria & $\%$ \\
\hline $\begin{array}{l}\text { Age Classification (Years): } \\
15-25 \text { years old } \\
\text { 26-35 years old } \\
\text { More than } 35 \text { years old }\end{array}$ & $\begin{array}{l}51,03 \\
38,77 \\
10,02\end{array}$ \\
\hline $\begin{array}{l}\text { First Age Starting to like the same sex or both: } \\
<12 \text { years old } \\
12-18 \text { years } \\
>19 \text { years }\end{array}$ & $\begin{array}{l}32,7 \\
44,2 \\
23,1\end{array}$ \\
\hline $\begin{array}{l}\text { Sex: } \\
\text { Male }\end{array}$ & $\begin{array}{l}83,70 \\
15,60\end{array}$ \\
\hline
\end{tabular}

\begin{tabular}{|l|c|}
\hline Female & 0,70 \\
Intersex & \\
\hline Educational backgroud: & 0,70 \\
No School & 2,70 \\
Elementary School & 10,9 \\
Junior High School & 71,40 \\
Senior High School & 14,30 \\
Higher Education & \\
\hline
\end{tabular}

Table 2. Distribution of respondent frequency based on LGBT behaviour history

\begin{tabular}{|l|l|}
\hline History of LGBT Behavior & $\mathbf{\%}$ \\
\hline Had a LGBT behavior brother and sister & 5,3 \\
\hline Be feminine to male and masculine to female & 10,0 \\
\hline Be hurt and disappointed by opposite & 14,0 \\
\hline Be sodomized when he was a achild for a male & 8,2 \\
\hline Got a sexual harassment & 8,4 \\
\hline Less harmony family (often got conflict and even divorce ) & 10,7 \\
\hline Be taught and cared by family opposite of the sex & 5,5 \\
\hline Be in the same environment with LGBT community & 13,8 \\
\hline Be seduced by the LGBT doers & 12,9 \\
\hline Lifestyle & 11,3 \\
\hline
\end{tabular}

The results in table 2 show that the greatest background history of LGBT behavior due to disappointment and harmed by the opposite sex for $14.0 \%$, and get influenced because they are in the same environment with LGBT community i.e. $13.8 \%$, and less harmonious families is $10.7 \%$. Furthermore, the Focused Group Discussion results and in-depth interviews also reveal that there are several factors underlying LGBT behavior, including environmental of playmates or social environment, less harmonious family, parenting patterns and socialization factors built in the family.

Table 3. Respondent distribution based on the LGBT sexual attitude and behaviour $(N=147)$

\begin{tabular}{|l|c|}
\hline \multicolumn{1}{|c|}{ LGBT Sexual Attitude and Behavior } & $\begin{array}{c}\text { Frequency } \\
(\mathbf{\%})\end{array}$ \\
\hline Behavior in Social Relation: & 81,60 \\
Tend to have the same sex orientation & 18,40 \\
Do not have the same orientation friend & \\
\hline & 71,40 \\
Behavior in LGBT Community Social Activity: & 28,60 \\
Do not follow the community organization & \\
Follow the community organization & \\
\hline & 54,40 \\
Permanent Sex partner: & 45,60 \\
Permanent & \\
Non permanent & 49,70 \\
\hline Sex Frequency Per Week: & 42,90 \\
1 time & 4,10 \\
$2-3$ times & 3,40 \\
\hline - 7 times & 15,60 \\
> times & 51,80 \\
\hline Location of Sex Activity: & 20,10 \\
Parent's House & 3,00 \\
Boarding House/Woman's Boarding House & 5,00 \\
Hotel/ Home stay & 4,50 \\
Tourism Place & 29,20 \\
Public Area & 14,9 \\
\hline Etc & \\
\hline Prevention of Health Problem: & \\
Take the antibiotics & \\
\hline
\end{tabular}


LGBT is a collective homework that must receive special attention from all parties. Apart from the pros and cons of the LGBT phenomenon, one thing that cannot be denied is that this issue has become a social fact occurring in the community, and it needs comprehensive and integrated prevention and control of LGBT with policy directions and action plans involving all parties or cross sector.

Some alternative policy directions in the prevention of LGBT are as follows:

Table 3 shows that the majorities of respondents' behavior in social relations are likely to have friends with the same sex orientation $(81.6 \%)$. These data are also supported by the results of in-depth interviews that they tend to gather and make friends with the same sex orientation because they feel more comfortable and can be more open to share stories / information. Furthermore, other respondents stated their attitude not to follow the community organizations $(71.4 \%)$.

The results of the study also reveal (table 3) that the proportion of respondents who do not have a permanent sex partner is $45.6 \%$. Furthermore, from the FGD results, it is found that, related to their sexual behavior, they are more likely to be loyal to their partner, and it is difficult to find another partner. If it is comfortable, they will tend to be loyal. Some people object if LGBT people are sex enthusiasts, but they prefer for comfortable. Furthermore, $49.7 \%$ of respondents say that they have sex frequency once per week and it is followed by 2 times and 3 times per week $(42.9 \%)$. However, the FGD results show that if they work as transvestites in the night. Their sexual behavior depends on the order, and they can do for 4 or 5 times. Customers also come from married men and look for satisfaction outside. Most of location/ place of respondents having sex is in their own boarding houses $(51.8 \%)$.

The results of the study (table 3) reveal that $29.2 \%$ of respondents prevent health problems by taking antibiotics and washing with toothpaste for $20.8 \%$. From the disease prevention, using condom and lubricant, it is relatively common for respondents to have sex. Almost $90 \%$ of respondents report that using condoms and $84 \%$ use lubricants in the last sex. The way of respondents to get the sex partners is through sexual relations in online media such as Facebook, WhatsApp, etc., which is equal to $58.7 \%$.

Regarding the Minangkabau culture's view of LGBT behavior, the majority of respondents says that they should not i.e $76.19 \%$. Furthermore, one of the efforts to change deviant sexual behavior is to provide guidance or assistance from religious experts and psychologists. It is revealed from the result of in-depth interviews with LGBT actors where some of them want favor from religious experts and psychologists. However, from quantitative data, it is revealed that the majority of respondents has never received the assistance of a psychologist (68.7\%) and the help of religious experts $(75.51 \%)$.

\section{Alternative Policy Directions}

1). Optimization of increasing knowledge about preventing LGBT behavior

By increasing the community's knowledge, it is expected that public will have better understanding and realize the dangers and impacts of LGBT behavior, especially, its impact on HIV /AIDS transmission.

Some alternative activities proposed are:

a. Increasing socialization for the prevention of LGBT behavior towards formal education by health experts and school teachers / Guidance and Counseling teachers /teachers starting from elementary school to Higher education periodically and continuously.

b. Improving counseling / mentoring guidance for children who become victims of sexual abuse and perpetrators through counseling teachers, psychologists and religious teachers.

Optimizing the counseling of the danger of LGBT behavior directly to the community involving religious leaders, community leaders, LKAM, Bundo Kanduang and $P K K$.

\section{2). Optimizing of strengthening the family resilience}

Strengthening resilience is very important in order to address LGBT behavior. This is because the causes of LGBT behavior caused by parenting factors and lack of harmony in the family. The proposed alternative activities are:

a. Improving family empowerment especially related to family parenting through Integrated Health Post and $P K K$ activities.

b. Regional regulations/ regulations related to family security.

3). Increasing an understanding and application of sociocultural and religious values in LGBT prevention efforts

As an effort to prevent LGBT behavior, it is necessary to have policies to support the improvement of understanding and application of socio-cultural values with several activities, namely:

a. Improving understanding of socio-cultural and religious values among students through formal education, especially regarding character, moral and religious education.

b. Optimizing of increasing mosque visits through preaching activities, Subuh education for mental 
development, behavior of children and adolescents in LGBT prevention efforts.

\section{4). Optimizing of supervision of the social environment}

Policies towards optimizing social environmental monitoring are needed for the prevention and response of LGBT behavior. Some activities that can be proposed are as follows:

a. Regulations / regional regulations related to security and public order and control of boarding / rented houses

b. Regulations for increasing social control at the district level (social/customary sanctions).

\section{DISCUSSION}

Adolescent is one of the groups that have great potential to get involved into certain sexual behavior groups because it is very close to the environment compared to families who are at risk of contracting HIV and risky behavior. It could be sexual behavior or drug injection. Most respondents $(32.7 \%)$ in this study have had sexual relations under 12 years old. If the respondent has limited health knowledge, the risk of transmission of HIV / AIDS tends to be greater. The results of research on stigma, violence \& discrimination of LGBT in Indonesia also reveal that the age of LGBT responsiveness is at most 19 to 24 years old i.e. $52.8 \%$.[7] This age group is in the active sexual phase and with a high frequency of sexual relations and changing partners and some, who are not compliant to use condoms, have a high risk of being infected with HIV and other sexually transmitted infections [8].

Educational background of most respondents are senior high school $(71.4 \%)$. The results of research conducted by Rosyad (2018) are also not much different where the most level of MSM education at Taratak Jiwa Hati Foundation is senior high school i.e 55.9\% [9].

There are several factors causing LGBT behavior, including environmental and family factors (parenting). The wrong application of family parenting by allowing boys play dolls can actually affect the perceptions, attitudes and behavior of children like women, and this behavior also affects their sexual orientation as an adolescent. The results of research conducted by Media (2015)[10] in Bukittinggi also reveal that the social environment with the community of gay and lesbian group and the lack of family care and less harmonious / incomplete family are factors contributing to the occurrence of doing sex with same sex. Furthermore, Lely (2011) [11] also suggest that the environment of peergroup is also important in matters of sexual behavior among adolescents. Closeness relations with peer-group tends to be relatively high, and this is not only due to peergroups can replace family ties, but they are also a source of affection, sympathy, understanding, and sharing experiences.

Related to social life in Minangkabau, Islam for the community is understood as a religion (ritual - sacred) and also as a way of life. Furthermore, in Minangkabau tradition, there is a custom philosophy based on religious law, namely "Adat Basandi Syarak, Syarak Basandi
Kitabullah" which means that the Minangkabau custom must be based on Islam, religion is based on Qur'an [12]. This is the cause of Islamic mode of Minangkabau society, so that, towards LGBT cases, all elements of the community feel shocked and denied this case and do not believe if the LGBT phenomenon occurring in Minangkabau. Furthermore, some people respond with anger and condemn the LGBT actions, which ultimately lead to the majority of LGBT people in West Sumatra choosing themselves to be introvert. From quantitative data, it reveals that most respondents do not join community organizations $(71.4 \%)$. The results of this study differ from the results of a study conducted by Laazulva (2013), in which the majority of respondents join into the community organizations (61.2\%) [7]. This difference is motivated by the existence of culture in West Sumatra that is identical with Islam and culture where the community is still guarding behavior in the community. Furthermore, Laazulva research is in 2013, while the author's time to conduct research is 2018, where LGBT phenomenon has been widely discussed and it becomes problem for all parties since last 3 years. It has an impact on the high stigma of LGBT groups where most of them do not join official community organizations, so that their identities are not known to the public. The results of research conducted by Puspita (2015) also reveal that some gays in Padang city choosing to be introvert gay because of the norms and culture in Padang City and most of the people are Moslem [13].

Some respondents $(45.6 \%)$ do not have permanent partners so that they will have high risk for HIV/AIDS transmission. Praptoraharjo's research results (2015) also reveal that transvestite respondents on the last day is almost half $(49 \%)$ of respondents saying they have sex, and the number of sex partners one day ranges from 1 to 7 people [14].

The place, where the most respondents have sex, is in their own boarding house. It is also revealed from the results of a Media study (2015) in Bukittinggi where boarding houses tend to be used by homosexuals to deviate behavior because the places are considered safer and do not need to get charged by some accommodation. It also could be from the lack of social control or supervision from the community [10].

From the prevention point of view, using condom and lubricant, it is relatively common for respondents to have sex. Safika Research, I (2013) also reveals that the use of $66 \%$ condoms at MSM in entertainment places, $84 \%$ is in massage parlors, and transvestite on the park is at 83\% [8]. Regarding to the Minangkabau culture's view of LGBT behavior, majority of respondents says that they should not (76.19\%). For the Minangkabau people (West Sumatra), there is a customary philosophy based on religious law, namely "Adat Basandi Syarak, Syarak Basandi Kitabullah," which means that the Minangkabau Adat must be based on Islam, Religion is based on Quran. This makes Islamic Minangkabau communities, which generally do not approve LGBT people in West Sumatra. This is in accordance with the first mission in the regional development of West Sumatra Province [15]. 
LGBT issue, from psychological point of view, is also considered that LGBT perpetrators can be cured, but there must be a will from themselves. They must believe that they want to be healed, and not many of LGBT people are aware of it. This is due to the feeling of being insulted in front of by other people. However, there is no human being is born by directly inheriting LGBT behavior but it would rather going through a long process, so that it has such distorted sexual orientation [4].

Efforts to change deviant sexual behavior can be done by providing guidance or assistance from religious experts and psychologists. However, from the results of the study, most of the respondents never get favor from psychologists and religious experts. In this case, spiritual guidance is one approach of guidance helping victims of sexual deviations. Religious spiritual guidance for child victims of sodomy can be done by providing religious leaders to provide reinforcement about religion, so that it can motivate sodomy victims to recover from trauma, take and accompany victims to places of worship such as mosques [16]. Efforts to prevent and deal with LGBT in a comprehensive or integrated with policy directions and action plans involving all parties or across sectors need to be considered and implemented. The proposed alternative policies include the optimization of increasing knowledge about preventing LGBT behavior by conducting socialization to the community through the world of education and direct counseling to the communities. This is because the public's knowledge about the impact of LGBT behavior on HIV/AIDS transmission is inadequate. Furthermore, there is also a need for policies related to strengthening the family resilience and monitoring the social environment as stated on the regional regulations.

\section{CONCLUSION}

Based on the results and discussion, it is concluded that the phenomenon of LGBT behavior in West Sumatra Province need to get serious attention. Most of LGBT people are at a young age, and the greatest first time for LGBT people to do the same sex or both is at $12-18$ years old and $<12$ years old. Perhaps, LGBT behavior is also motivated by a disappointed feeling from an opposite sex, being in the same environment with LGBT community, and the family is less harmonious. Boarding house is the most common place for LGBT people to do deviant sexual behavior. Most respondents never get the help from religious experts and psychologists. Alternative policy directions and prepared action plans are expected to be solution in making health development policies, especially HIV/AIDS prevention.

Recommendations from this research are the direction of policies and action plans in the prevention of LGBT efforts need to be implemented in an integrated manner, namely: 1) increasing knowledge about LGBT prevention through counseling involving religious leaders and Bundo Kanduang, 2). optimization of family resilience strengthening through family empowerment and proposed regional regulations on family resilience, 3 ). increasing the application of socio-cultural and religious values by increasing mosque visits (Adolescent Preaching Activities and Subuh education), 4). Optimization of supervision of the social environment through regulations or district regulations related to public order.

\section{REFERENCES}

[1] Zaini H. LGBT dalam perspektif hukum Islam. Jurnal Ilmiah Syari'ah, Volume 15, Nomor 1, Januari-Juni 2016: 65-73

[2] Dinas Kesehatan Provinsi Sumatera Barat, 2018. Situasi HIV/AIDS di Sumatera Barat. Bahan disampaikan pada Rakor penanganan LGBT di Sumatera Barat. Padang 11 Januari 2018.

[3] Kementerian Kesehatan. Laporan Situasi Perkembangan HIV-AIDS \& PIMS di Indonesia Januari Desember 2017.

[4] Saleh G, Arif M. Perilaku LGBT dalam tinjauan sosial. Volume 2 September 2017. Prosiding 2th Celscitech-UMRI 2017.

[5] Sijabat FN, Setyawan H, Sofro MA, Hadisaputro S. Lelaki Seks Lelaki, HIV/AIDS dan perilaku Seksualnya di Semarang. Jurnal Kesehatan Reproduksi, 8(2), 2017: 131142.

[6] Cresswell. Research design pendekatan kualitatif, kuantitatif, dan Mixed. Yogyakarta: Pustaka Pelajar;2009.

[7] Laazulva. Menguak stigma, kekerasan \& diskriminasi pada LGBT Di Indonesia, Arus Pelangi; , 2013.

[8] Safika, I et all. Condom Use Among Men Who Have Sex With Men and Male-to-Female Transgenders in Jakarta, Indonesia, American Journal of Men's Health 2013 8:4, 278-288.

[9] Rosyad, yopi. Hubungan efikasi diri dan makna hidup dengan kepatuhan pengobatan antiretroviral therapy (Art) pada Lelaki Seks Lelaki Seropositif Hiv Di Yayasan Taratak Jiwa Hati Sumatera Barat, Universitas Andalas; 2018.

[10] Media, Yulfira. Faktor yang melatarbelakangi penularan HIV/AIDS di Bukittinggi (Sumatera Barat)". Jurnal Pembangunan Manusia, Balitbangda Sumatera Selatan/ Jurnal Nasional Terakreditasi Vol. 9, No. 2 Agustus 2015.

[11] Lely, Niniek P. Hubungan karakteristik remaja terkait risiko penularan HiV-AIDS dan perilaku seks tidak aman di Indonesia. Buletin Penelitian Sistem Kesehatan, Vol.14 No.4 Oktober 2011

[12] Salmadanis \& Samad, D. Adat basandi syarak: nilai dan aplikasinya menuju kembali ke nagari dan surau. Jakarta: Kartina Insan Lestari; 2003.

[13] Puspita, Yeni . Pemanfaatan new media dalam memudahkan komunikasi dan transaksi pelacur Gay. Jurnal Pekommas Volume 18 Edisi 3, Desember 2015.

[14] Praptoraharjo, I dkk. Survey kualitas hidup waria, Pusat penelitian HIV/AIDS, UNIKA Atma Jaya; 2015.

[15] Pemerintahan Provinsi Sumatera Barat. Peraturan Daerah Provinsi Sumatera Barat Nomor 6 Tahun 2016 tentang Rencana Pembangunan Jangka Menengah (RPJM) Derah Provinsi Sumatera Barat (2016-2021). 
[16] Sulaiman. Faktor Penyimpangan Perilaku LGBT. At-

Ta'dib: Vol. IX, No. 1, Januari - Juni 2017 